\title{
HDAC9 Gene
}

National Cancer Institute

\section{Source}

National Cancer Institute. HDAC9 Gene. NCI Thesaurus. Code C102492.

This gene plays a role in chromatin modification. 